\title{
Halarchaeum acidiphilum gen. nov., sp. nov., a moderately acidophilic haloarchaeon isolated from commercial solar salt
}

Correspondence
Hiroaki Minegishi
minehiro@toyonet.toyo.ac.jp

\author{
Hiroaki Minegishi, ${ }^{1}$ Akinobu Echigo, ${ }^{1}$ Shuhei Nagaoka, ${ }^{2}$ \\ Masahiro Kamekura ${ }^{3}$ and Ron Usami ${ }^{1,4}$ \\ ${ }^{1}$ Bio-Nano Electronics Research Center, Toyo University, Kawagoe-shi, Saitama, Japan \\ ${ }^{2}$ Department of Biological Applied Chemistry, Graduate School of Engineering, Toyo University, \\ Kawagoe-shi, Saitama, Japan \\ ${ }^{3}$ Halophiles Research Institute, Noda-shi, Chiba, Japan \\ ${ }^{4}$ Graduate School of Interdisciplinary New Science, Toyo University, Kawagoe-shi, Saitama, Japan
}

Halophilic archaea are classified within the family Halobacteriaceae of the order Halobacteriales. The family Halobacteriaceae consists of a large group of aerobic microbes that live and grow in hypersaline environments such as salt lakes, salterns, solar salts and subsurface salt formations. Recently, it has been suggested that haloarchaeal strains can grow within saline microniches in nonsaline environments, and the novel haloarchaeal species Haladaptatus paucihalophilus and Halosarcina pallida were isolated from a spring with a low salt concentration (Savage et al., 2007, 2008). Recent studies have reported that some strains can survive for several days in distilled water or $0.5 \%$ salt solution (Savage et al., 2007; Fukushima et al., 2007). These studies have shown that the order Halobacteriales is more diverse than previously believed.

Abbreviations: $\mathrm{ML}$, maximum-likelihood; NJ, neighbour-joining.

The GenBank/EMBL/DDBJ accession number for the 16S rRNA gene sequence of strain $\mathrm{MH} 1-52-1^{\top}$ is $\mathrm{AB} 371717$.

Growth curves at different $\mathrm{pH}$ values and $\mathrm{Mg}^{2+}$ concentrations, a TLC plate showing polar lipids and a 16S rRNA gene sequence-based maximum-likelihood tree are available as supplementary material with the online version of this paper.
Currently, haloarchaeal strains are classified in 27 genera that display a wide variety of physiological characteristics including range of $\mathrm{pH}$ for growth. Optimal growth occurs either at neutral to slightly alkaline $\mathrm{pH}$ or only at alkaline $\mathrm{pH}$. Halococcus hamelinensis $100 \mathrm{~A}^{\mathrm{T}}$ and Halococcus qingdaonensis $\mathrm{CM} 5^{\mathrm{T}}$ are exceptions, in being able to grow at acidic $\mathrm{pH}$ (4.0), but they grow up to $\mathrm{pH} 9.0$, with optimum growth at pH 6.0 (Goh et al., 2006; Wang et al., 2007).

In a previous study, we isolated a few strains of moderately acidophilic haloarchaea able to grow only at $\mathrm{pH} 4.0-6.0$ from solar salt samples commercially available in Japan (Minegishi et al., 2008). In the present study, we report on the phylogenetic and phenotypic characterization of a representative strain, MH1-52-1 ${ }^{\mathrm{T}}$. We propose that the strain represents a novel genus and species.

Strain MH1-52-1 ${ }^{\mathrm{T}}$ was isolated from solar salt imported from Australia. A salt sample (1.0 g) was dissolved in $4 \mathrm{ml} \mathrm{MH1}$ medium [containing $\left(1^{-1}\right) 4.0 \mathrm{~g}$ Casamino acids (Difco), $2.0 \mathrm{~g}$ yeast extract (Difco), $2.0 \mathrm{~g}$ L-glutamic acid, $2.0 \mathrm{~g}$ trisodium citrate dihydrate, $5.0 \mathrm{~g} \mathrm{~K}_{2} \mathrm{SO}_{4}, 1.0 \mathrm{~g} \mathrm{MgCl}_{2} .6 \mathrm{H}_{2} \mathrm{O}(5 \mathrm{mM})$, $1.0 \mathrm{~g} \mathrm{NH}_{4} \mathrm{Cl}, 1.0 \mathrm{~g} \mathrm{KH}_{2} \mathrm{PO}_{4}, 0.004 \mathrm{~g} \mathrm{FeSO}_{4} \cdot 7 \mathrm{H}_{2} \mathrm{O}, 200 \mathrm{~g}$ 
$\mathrm{NaCl}, 2.0 \mathrm{ml}$ trace metal solution] adjusted to $\mathrm{pH} 4.5$ with $40 \% \mathrm{KOH}$. In some experiments, the $\mathrm{pH}$ was adjusted to $3.5-$ 6.5 at intervals of 0.2 or $0.5 \mathrm{pH}$ units and the $\mathrm{NaCl}$ and $\mathrm{MgCl}_{2} \cdot 6 \mathrm{H}_{2} \mathrm{O}$ concentrations were modified as described below. The trace metal solution contained $\left(\mathrm{l}^{-1}\right) 2.0 \mathrm{~g}$ $\mathrm{Na}_{2} \mathrm{~S}_{2} \mathrm{O}_{3} \cdot 5 \mathrm{H}_{2} \mathrm{O}, 1.0 \mathrm{~g} \mathrm{CaCl}_{2} .2 \mathrm{H}_{2} \mathrm{O}, 0.3 \mathrm{~g} \mathrm{CoCl} \cdot 6 \mathrm{H}_{2} \mathrm{O}$, $0.1 \mathrm{~g} \mathrm{BaCl}_{2} .2 \mathrm{H}_{2} \mathrm{O}, 0.1 \mathrm{~g} \mathrm{MnCl}_{2} .4 \mathrm{H}_{2} \mathrm{O}, 0.1 \mathrm{~g} \mathrm{ZnCl}_{2}, 0.1 \mathrm{~g}$ $\mathrm{Na}_{2} \mathrm{MoO}_{4} .2 \mathrm{H}_{2} \mathrm{O}, 0.1 \mathrm{~g} \mathrm{NiCl}_{2} .6 \mathrm{H}_{2} \mathrm{O}, 0.04 \mathrm{~g} \mathrm{AlCl}_{3}, 0.02 \mathrm{~g}$ $\mathrm{Na}_{2} \mathrm{WO}_{4} \cdot 2 \mathrm{H}_{2} \mathrm{O}$ and $0.02 \mathrm{~g} \mathrm{H}_{3} \mathrm{BO}_{3}$, adjusted to $\mathrm{pH} 4.0$ with $2.0 \mathrm{M} \mathrm{HCl}$. The medium was autoclaved for $20 \mathrm{~min}$ at $121{ }^{\circ} \mathrm{C}$. There was no change in the $\mathrm{pH}$ of the medium after autoclaving.

After incubation at $37{ }^{\circ} \mathrm{C}$ for 1 week without shaking, $0.1 \mathrm{ml}$ of the culture was spread evenly on an $\mathrm{MH} 1$ agar plate (pH 4.5), solidified with 20 g Bacto agar (Difco) $1^{-1}$. After incubation at $37{ }^{\circ} \mathrm{C}$ for 2 weeks, colonies were picked up and transferred to fresh agar plates at the same $\mathrm{pH}$ and pure cultures were obtained by plating serial dilutions and repeated transfers on agar plates.

Phenotypic tests were performed according to the proposed minimal standards for the descriptions of new taxa in the order Halobacteriales (Oren et al., 1997). Physiological and chemotaxonomic analyses were conducted using liquid or solidified MH1 medium at $37{ }^{\circ} \mathrm{C}$. Liquid cultures were incubated on a shaking incubator at 100 r.p.m. Growth rates were determined by monitoring the increase in $\mathrm{OD}_{600}(1 \mathrm{~cm}$ light path).

Colonies of strain MH1-52-1 ${ }^{\mathrm{T}}$ were circular, smooth and non-pigmented after incubation for 7 days at $37^{\circ} \mathrm{C}$. Pigmentation was not observed even after 3-4 weeks of incubation. Cell morphology was studied using phasecontrast microscopy (Zeiss Axiovert 135). Cells were Gramnegative, non-motile and pleomorphic, with triangular and disc morphology, approximately $1.5-2.0 \times 2.0-2.5 \mu \mathrm{m}$, and lysed in distilled water. The temperature range for growth was $15-45^{\circ} \mathrm{C}$, with optimum growth at $37^{\circ} \mathrm{C}$. Growth in liquid $\mathrm{MH} 1$ medium ( $5 \mathrm{mM} \mathrm{Mg}^{2+}$ ) occurred at $\mathrm{pH} 4.2-$ 4.8 , with optimum growth at $\mathrm{pH} 4.4\left(\mathrm{OD}_{600} 1.5\right.$ after 4 days). $\mathrm{NaCl}$ and $\mathrm{MgCl}_{2} \cdot 6 \mathrm{H}_{2} \mathrm{O}$ tolerance was tested at $\mathrm{pH} 4.5$ and $37^{\circ} \mathrm{C}$. Strain MH1-52-1 $1^{\mathrm{T}}$ grew in $18-30 \%(\mathrm{w} / \mathrm{v})$ $\mathrm{NaCl}$, with optimum growth at $21-24 \%(\mathrm{w} / \mathrm{v}) \mathrm{NaCl}$. Growth was observed from $1 \mathrm{mM}\left(\mathrm{OD}_{600} 0.6\right.$ after 4 days) up to $500 \mathrm{mM}\left(\mathrm{OD}_{600} 0.8\right.$ after 3 days) $\mathrm{Mg}^{2+}$ in medium with $20 \%(\mathrm{w} / \mathrm{v}) \mathrm{NaCl}$, with an optimum at $50 \mathrm{mM}$. In medium with $250 \mathrm{mM} \mathrm{Mg}^{2+}$, growth was observed over a slightly broader $\mathrm{pH}$ range of 4.0-6.0 with an optimum at $\mathrm{pH} 4.5$ after incubation for 3 days. Cells aggregated in medium containing more than $20 \mathrm{mM} \mathrm{Mg}^{2+}$ after incubation for 7 days. The $\mathrm{pH}$ of the medium was measured during growth in medium buffered with $100 \mathrm{mM}$ citrate adjusted to 4.4 and 4.6 (Supplementary Fig. S1, available in IJSEM Online). The $\mathrm{pH}$ did not change until cell growth reached an $\mathrm{OD}_{600}$ of 1.2 and then a gradual increase in $\mathrm{pH}$ was observed (Supplementary Fig. S1c, d). According to Johnson (2007), there is no common agreement on the $\mathrm{pH}$ boundary that delineates acidophily in micro-organisms, but a useful guide is that extreme acidophiles have an optimum $\mathrm{pH}$ for growth of $<3.0$ and that moderate acidophiles grow optimally at $\mathrm{pH} 3-5$. We believe that strain MH1-52-1 ${ }^{\mathrm{T}}$ is the first moderate acidophile reported in the Halobacteriaceae.

Antibiotic sensitivity was determined by using BD SensiDiscs (Becton Dickinson) except for discs containing anisomycin and pravastatin, which were prepared in our laboratory. Strain MH1-52-1 $1^{\mathrm{T}}$ was sensitive to (per disc) anisomycin $(50 \mu \mathrm{g})$, bacitracin $(10 \mathrm{U})$, novobiocin $(30 \mu \mathrm{g})$, pravastatin $(50 \mu \mathrm{g})$, rifampicin $(5 \mu \mathrm{g})$ and tetracycline $(30 \mu \mathrm{g})$ and resistant to ampicillin $(10 \mu \mathrm{g})$, chloramphenicol $(30 \mu \mathrm{g})$, erythromycin $(15 \mu \mathrm{g})$, gentamicin $(120 \mu \mathrm{g})$, kanamycin $(30 \mu \mathrm{g})$, neomycin $(30 \mu \mathrm{g})$, penicillin $\mathrm{G}(10 \mathrm{U})$, streptomycin $(300 \mu \mathrm{g})$ and vancomycin $(30 \mu \mathrm{g})$.

Strain MH1-52-1 ${ }^{\mathrm{T}}$ was catalase- and oxidase-negative and did not hydrolyse starch, gelatin, casein or Tween 80. Reduction of nitrate was not detected by using the sulfanilic acid and $\alpha$ naphthylamine reagent (Smibert \& Krieg, 1994). Detailed physiological and biochemical characteristics of strain MH1$52-1^{\mathrm{T}}$ are listed in the species description and in Table 1.

Polar lipids were extracted with chloroform/methanol as described previously (Kamekura, 1993). TLC was performed by using HPTLC silica gel 60 plates $(20 \times 10 \mathrm{~cm}$; Merck) in the solvent system chloroform/methanol/acetic acid/water (85:22.5:10:4, by vol.). Glycolipids were detected as purple spots by spraying with $0.5 \%(\mathrm{w} / \mathrm{v}) \alpha-$ naphthol in methanol/water $(1: 1)$ and then with sulfuric acid/ethanol $(1: 1)$, followed by heating at $160{ }^{\circ} \mathrm{C}$. Strain MH1-52-1 $1^{\mathrm{T}}$ contained phosphatidylglycerol and phosphatidylglycerol phosphate methyl ester as phospholipids, derived from both $\mathrm{C}_{20} \mathrm{C}_{20}$ and $\mathrm{C}_{20} \mathrm{C}_{25}$ archaeol (double spots), but not phosphatidylglycerol sulfate. Strain MH1$52-1^{\mathrm{T}}$ contained at least four glycolipids that have yet to be identified (see Supplementary Fig. S2), although the two overlapping spots might represent $\mathrm{C}_{20} \mathrm{C}_{20}$ and $\mathrm{C}_{20} \mathrm{C}_{25}$ moieties of a glycolipid. Strain MH1-52-1 ${ }^{\mathrm{T}}$ may be distinguished from all other known members of the family Halobacteriaceae on the basis of its polar lipids.

Total DNA was extracted by the method of Cline et al. (1989). The G + C content of the total DNA of strain MH1$52-1^{\mathrm{T}}$, determined by the HPLC method of Tamaoka \& Komagata (1984), was $61.4 \mathrm{~mol} \%$. The $16 \mathrm{~S}$ rRNA gene was amplified by PCR with forward and reverse primers $5^{\prime}$ ATTCCGGTTGATCCTGCCGG-3' and 5'-AGGAGGTGATCCAGCCGCAG-3'. Amplified DNA was cloned by using the TA Cloning kit (Invitrogen) and sequenced using the ABI PRISM BigDye Terminator version 3.1 cycle sequencing kit (Applied Biosystems) with the following primers: $611 \mathrm{~F}\left(5^{\prime}\right.$-GGTACGTCCGGGGTAGGAGT- $\left.3^{\prime}\right)$ and 860R (5'-CCTTTAAGTTTCATCCTTGC-3') (primers designed in this work) and -20 (5'-GGAAACAGCTATGACCATG-3') and Rev (5'-GTAAAACGACGGCCAGT-3') (vector-side primers) on an ABI PRISM 310 Genetic Analyzer (Applied Biosystems). The sequence of strain MH1-52-1 ${ }^{\mathrm{T}}(1430 \mathrm{bp})$ was closest to that of Halobacterium noricense $\mathrm{Al}^{\mathrm{T}}$, with $91.7 \%$ similarity. Sequences of related 
Table 1. Differential characteristics between strain $\mathrm{MH} 1-52-1^{\top}$ and closely related genera within the order Halobacteriales

Taxa: 1, strain MH1-52-1 ${ }^{\mathrm{T}}$; 2, Halobacterium; 3, Halococcus; 4, Haloferax; 5, Halorubrum. Data for reference genera were taken from Savage et al. (2008), Yachai et al. (2008) and Oren et al. (2009). +, Positive; -, negative; +/-, variable depending on the species.

\begin{tabular}{|c|c|c|c|c|c|}
\hline Characteristic & 1 & 2 & 3 & 4 & 5 \\
\hline Motility & - & + & - & $+1-$ & $+1-$ \\
\hline Temperature optimum $\left({ }^{\circ} \mathrm{C}\right)$ & 37 & $37-45$ & $30-40$ & $32-50$ & $37-50$ \\
\hline $\mathrm{pH}$ optimum & 4.4 & $7.0-7.5$ & $6.8-9.5$ & $6.4-7.5$ & $7.0-7.5 / 9.0-10.0$ \\
\hline Lysis in distilled water & + & + & - & + & + \\
\hline
\end{tabular}

strains retrieved from the DNA Data Bank of Japan (Miyazaki et al., 2003; Pearson \& Lipman, 1988; Lipman \& Pearson, 1985) were aligned using CLUSTAL_X 2.0.10 (Larkin et al., 2007). A phylogenetic tree was reconstructed by using the neighbour-joining (NJ) method (Saitou \& Nei, 1987) and evaluated by bootstrap sampling (Felsenstein, 1985). Maximum-likelihood (ML) analyses were performed with RAxML 7.0.4 using the GTR $+\Gamma$ model (Stamatakis et al., 2005). Support values for the ML tree were obtained by bootstrapping (1000 replicates) using CONSENSE in PHYLIP (Felsenstein, 2002). The NJ tree (Fig. 1) and ML tree (Supplementary Fig. S3) showed that strain MH1-52-1 ${ }^{\mathrm{T}}$ was a member of the family Halobacteriaceae and was most closely related to the species of the genus Halobacterium. However, strain MH1-52-1 ${ }^{\mathrm{T}}$ was distinctly differentiated from the Halobacterium species (Oren et al., 2009) in motility, morphology, pigmentation, catalase activity, growth $\mathrm{pH}$ range, presence/absence of the $\mathrm{C}_{20} \mathrm{C}_{25}$ isoprenoid moiety and the glycolipid profile.

The phylogenetic and phenotypic characteristics outlined above indicate that strain $\mathrm{MH} 1-52-\mathrm{1}^{\mathrm{T}}$ represents a novel genus and species, for which the name Halarchaeum acidiphilum gen. nov., sp. nov. is proposed.

\section{Description of Halarchaeum gen. nov.}

Halarchaeum (Hal'ar.chae' um. Gr. n. hals, halos salt, salt water; N.L. n. archaeum ancient one, archaeon, from Gr. adj. archaios ancient; N.L. neut. n. Halarchaeum a saline archaeon).

Cells are non-motile, Gram-negative and pleomorphic, with triangular and disc morphology. Cells contain phosphatidylglycerol and phosphatidylglycerol phosphate methyl ester, derived from both $\mathrm{C}_{20} \mathrm{C}_{20}$ and $\mathrm{C}_{20} \mathrm{C}_{25}$ archaeol, and four unidentified glycolipids. Cells lyse in distilled water. Chemo-organotrophic, growing on a wide range of substrates, including single and complex carbon sources. The type species is Halarchaeum acidiphilum. Recommended three-letter abbreviation: Hla.

\section{Description of Halarchaeum acidiphilum sp. nov.}

Halarchaeum acidiphilum (a.ci'di.phi'lum. N.L. neut. n. acidum acid; Gr. adj. philos loving; N.L. neut. adj. acidiphilum acid-loving).

Exhibits the following properties in addition to those given in the genus description. Cells are approximately $2.0 \mu \mathrm{m}$ in diameter. Colonies are approximately $1.0 \mathrm{~mm}$ in diameter, circular, smooth and non-pigmented. Grows in 18-30\% (w/v) $\mathrm{NaCl}$, with optimum growth at 21-24\% (w/v) $\mathrm{NaCl}$. A minimum of $1 \mathrm{mM} \mathrm{Mg}^{2+}$ is required for growth. Optimal temperature for growth is $37^{\circ} \mathrm{C}$ (range, 15$45{ }^{\circ} \mathrm{C}$ ). Moderately acidophilic; grows at initial pH 4.0-6.0, with an optimum at $\mathrm{pH}$ 4.4-4.5. Does not grow anaerobically with nitrate or DMSO. Does not ferment arginine.

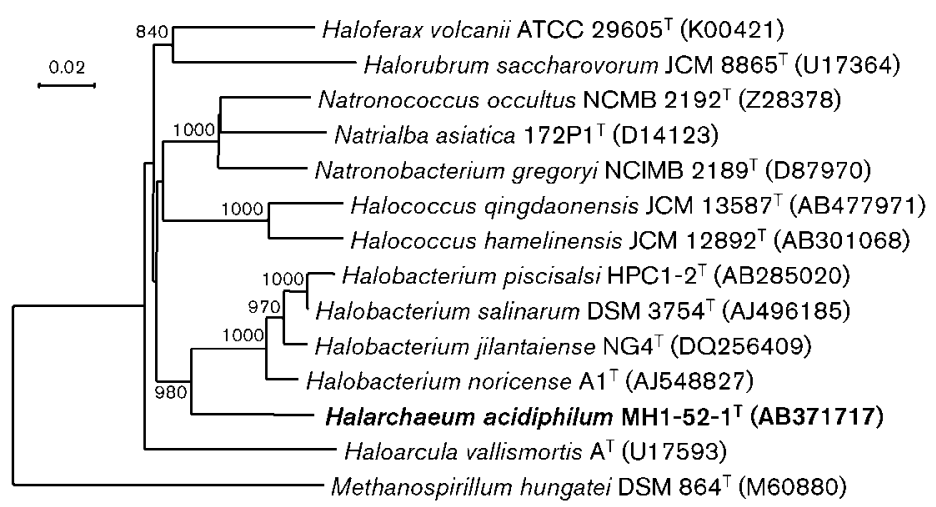

Fig. 1. Neighbour-joining phylogenetic tree based on 16S rRNA gene sequences showing the position of strain $\mathrm{MH} 1-52-1^{\top}$ and related haloarchaeal strains. Bootstrap values are shown as percentages of 1000 replicates. GenBank accession numbers are shown in parentheses. Bar, 0.02 changes per nucleotide position. 
Capable of using the following single carbon substrates: arabinose, cellobiose, fructose, galactose, glucose, glycerol, ribitol, raffinose, sucrose and xylose. Lactose, maltose, mannitol, mannose, ribose, sorbitol, trehalose, citrate and glutamate are not utilized as carbon sources. Able to utilize complex carbon sources such as yeast extract. Sensitive to anisomycin, bacitracin, novobiocin, pravastatin, rifampicin and tetracycline. Resistant to ampicillin, chloramphenicol, erythromycin, gentamicin, kanamycin, neomycin, penicillin, streptomycin and vancomycin. Catalase- and oxidasenegative. Gelatin, starch, casein and Tween 80 are not hydrolysed. Indole is not produced from tryptophan. $\mathrm{H}_{2} \mathrm{~S}$ is not produced from thiosulfate. Does not reduce nitrate under aerobic conditions. The DNA G $+\mathrm{C}$ content of the type strain is $61.4 \mathrm{~mol} \%$.

The type strain is MH1-52-1 $1^{\mathrm{T}}\left(=\mathrm{JCM} 16109^{\mathrm{T}}=\mathrm{DSM}\right.$ $22442^{\mathrm{T}}=$ CECT $7534^{\mathrm{T}}$ ), isolated from solar salt imported into Japan from Australia.

\section{References}

Cline, S. W., Schalkwyk, L. C. \& Doolittle, W. F. (1989). Transformation of the archaebacterium Halobacterium volcanii with genomic DNA. J Bacteriol 171, 4987-4991.

Felsenstein, J. (1985). Confidence limits on phylogenies: an approach using the bootstrap. Evolution 39, 783-791.

Felsenstein, J. (2002). PHYLIP (phylogeny inference package), version 3.6a. Distributed by the author. Department of Genome Sciences, University of Washington, Seattle, USA.

Fukushima, T., Usami, R. \& Kamekura, M. (2007). A traditional Japanese-style salt field is a niche for haloarchaeal strains that can survive in $0.5 \%$ salt solution. Saline Syst 3, 2 .

Goh, F., Leuko, S., Allen, M. A., Bowman, J. P., Kamekura, M., Neilan, B. A. \& Burns, B. P. (2006). Halococcus hamelinensis sp. nov., a novel halophilic archaeon isolated from stromatolites in Shark Bay, Australia. Int J Syst Evol Microbiol 56, 1323-1329.

Johnson, D. B. (2007). Physiology and ecology of acidophilic microorganisms. In Physiology and Biochemistry of Extremophiles, pp. 257-270. Edited by C. Gerday \& N. Glansdorff. Washington, DC: American Society for Microbiology.

Kamekura, M. (1993). Lipids of extreme halophiles. In The Biology of Halophilic Bacteria, pp. 135-161. Edited by R. H. Vreeland \& L. I. Hochstein. Boca Raton, FL: CRC Press.
Larkin, M. A., Blackshields, G., Brown, N. P., Chenna, R., McGettigan, P. A., McWilliam, H., Valentin, F., Wallace, I. M., Wilm, A. \& other authors (2007). CLUSTAL W and CLUSTAL_X version 2.0. Bioinformatics 23, 2947-2948.

Lipman, D. J. \& Pearson, W. R. (1985). Rapid and sensitive protein similarity searches. Science 227, 1435-1441.

Minegishi, H., Mizuki, T., Echigo, A., Fukushima, T., Kamekura, M. \& Usami, R. (2008). Acidophilic haloarchaeal strains are isolated from various solar salts. Saline Syst 4, 16.

Miyazaki, S., Sugawara, H., Gojobori, T. \& Tateno, Y. (2003). DNA Data Bank of Japan (DDBJ) in XML. Nucleic Acids Res 31, 13-16.

Oren, A., Ventosa, A. \& Grant, W. D. (1997). Proposed minimal standards for description of new taxa in the order Halobacteriales. Int J Syst Bacteriol 47, 233-238.

Oren, A., Arahal, D. R. \& Ventosa, A. (2009). Emended descriptions of genera of the family Halobacteriaceae. Int J Syst Evol Microbiol 59, 637-642.

Pearson, W. R. \& Lipman, D. J. (1988). Improved tools for biological sequence comparison. Proc Natl Acad Sci U S A 85, 2444-2448.

Saitou, N. \& Nei, M. (1987). The neighbor-joining method: a new method for reconstructing phylogenetic trees. Mol Biol Evol 4, 406-425.

Savage, K. N., Krumholz, L. R., Oren, A. \& Elshahed, M. S. (2007). Haladaptatus paucihalophilus gen. nov., sp. nov., a halophilic archaeon isolated from a low-salt, sulfide-rich spring. Int J Syst Evol Microbiol 57, 19-24.

Savage, K. N., Krumholz, L. R., Oren, A. \& Elshahed, M. S. (2008). Halosarcina pallida gen. nov., sp. nov., a halophilic archaeon from a low-salt, sulfide-rich spring. Int J Syst Evol Microbiol 58, 856-860.

Smibert, R. M. \& Krieg, N. R. (1994). Phenotypic characterization. In Methods for General and Molecular Bacteriology, pp. 607-654. Edited by P. Gerhardt. Washington, DC: American Society for Microbiology.

Stamatakis, A., Ludwig, T. \& Meier, H. (2005). RAxML-III: a fast program for maximum likelihood-based inference of large phylogenetic trees. Bioinformatics 21, 456-463.

Tamaoka, J. \& Komagata, K. (1984). Determination of DNA base composition by reversed-phase high-performance liquid chromatography. FEMS Microbiol Lett 25, 125-128.

Wang, Q.-F., Li, W., Yang, H., Liu, Y.-L., Cao, H.-H., DornmayrPfaffenhuemer, M., Stan-Lotter, H. \& Guo, G.-O. (2007). Halococcus qingdaonensis sp. nov., a halophilic archaeon isolated from a crude sea-salt sample. Int J Syst Evol Microbiol 57, 600-604.

Yachai, M., Tanasupawat, S., Itoh, T., Benjakul, S., Visessanguan, W. \& Valyasevi, R. (2008). Halobacterium piscisalsi sp. nov., from fermented fish (pla-ra) in Thailand. Int J Syst Evol Microbiol 58, 2136-2140. 